DOI 10.37882/2223-2974.2020.09.16

\title{
ЖЕНСКАЯ БЕЗРАБОТИЦА: ПУТИ РЕШЕНИЯ
}

\section{FEMALE UNEMPLOYMENT: THE WAY FORWARD}

\section{T. Matveeva \\ N. Kuznetsova \\ O. Ryabova \\ M. Kolbaya}

Summary: Nowadays, there is an uncompromising struggle on the part of the female sex to defend personal rights in all aspects of life. This phenomenon has not spared the representatives of our country. Women's employment is a constant focus. Increased unemployment in the second half of 2020, including women's unemployment, most clearly demonstrates this phenomenon in Russia.

Keywords: women's unemployment, labor market, gender inequality, workplace, state.

\section{Матвеева Тамара Павловна}

старший преподаватель, ФКОУ ВО «Владимирский юридический институт ФСИН России»

matveeva33@mail.ru

Кузнецова Наталья Александровна

старший преподаватель, ФКОУ ВО «Владимирский юридический институт ФСИН России»

kuz1503@yandex.ru

Рябова Ольга Алексеевна

Преподаватель, ФКОУ ВО «Владимирский юридический институm ФСИН России» frau.lelya2012@yandex.ru

Колбая Мэри Мерабовна

ФКОУ ВО «Владимирский юридический институт ФСИН Poccuu»

meri.kolbaya@mail.ru

Аннотация: В наши дни ведётся бескомпромиссная борьба со стороны женского пола за отстаивание личных прав касательно всех аспектов жизни. Данное явление не обошло стороной и представительниц нашего Отечества. Женская занятость постоянно является предметом внимания. Возросшая безработица второго полугодия 2020 года, в том числе и женская, наиболее ясно демонстрирует данное явление России.

Ключевые слова: женская безработица, рынок труда, гендерное неравенство, рабочее место, государство.

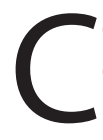
овременное российское общество доводит до огласки проблематику гендерного неравенства при использовании и реализации социально-трудовых прав. В настоящий момент порядка половины трудоспособных женщин остаются незанятыми какой-либо оплачиваемой и регулируемой трудовым законодательством деятельностью. Подлинные причины этого явления показывает исторический анализ социально-экономических проблем в России на протяжении последних 30 лет.

Нестабильный и непланомерный переход к современному государственному устройству «подкосил» не только отрасли экономики с целью перехода и установления капиталистической формации, но в первую очередь усугубил трудовые отношения и культуру со всеми вытекающими. В новой российской истории этот период носит ответную неблагоприятную реакцию народа на гнёт со стороны государственного аппарата по поводу любого проявления свобод и закрепления собственных интересов, превалирующих над интересами общества. Беззаконие и пренебрежение общечеловеческими принципами и устоями обесценили не только физический и умственный труд, а также отношение к нему со стороны бывшего рабочего класса. Именно эти эпизоды послужили отправной точкой нынешнего положения на рынке труда, сводящего к минимуму участие женщин в трудовой деятельности. А ведь отношения в сфере занятости населения являются основополагающими в экономике любого государства. Проблемы, существующие на рынке труда оказывают влияние на все стороны жизни государства, на его развитие и требуют решений.

В наши дни безработицей именуется состояние внутренней экономики, при которой часть трудоспособного и экономически активного населения по определённым обстоятельствам не может найти или устроиться на работу, хотя заинтересованы в этом и проявляют гражданскую активность. По методологическим исследованиям Росстата на территории Российской Федерации промежуток трудовой жизни без ущерба здоровью и развитию человека составляет от 15 до 72 лет. Несмотря на то, что уровень этого явления на сегодняшний день находится в границах установленной нормы и составляет 4,7\%, но в большинстве случаев она негативно влияет на макроэкономический потенциал и замедляет темпы роста благополучия граждан. Феномен безработицы обязателен как необходимый запас рабочей силы, по причине этого большинство стран не оценивают его сугубо 
отрицательно. Грамотное распределение ресурсов и трудового резерва повышают эффективность государственной политики, однако постоянство упомянутого порядка вещей определило его постоянный характер.

По данным Федеральной службы государственной статистики в январе 2020 года 74,8 миллионов человек считались трудоспособными, 3,5 миллионов из которых были признаны безработными, доля женщин из них составила 47,4\%, городских жителей - 68,2\%, молодёжи до 25 лет - 18,5\%, лиц без трудового опыта - 21,2\%. Приведённая статистика показывает, что средства по улучшению трудозанятости не работают для широких масс. По сравнению с 2019 годом на всех уровнях количество безработных возросло [1].

С наступлением карантина по коронавирусу, который охватил население нашей страны с апреля 2020 года данная картина изменилась в худшую сторону и на сегодняшний момент нельзя сказать о его прекращении. В связи с пандемией в России оказался незанятым каждый десятый трудоспособный россиянин. Работников массово отправляли в вынужденные отпуска, происходили сокращения, снижение зарплат и отмена премий. Так из-за карантинных мер в вынужденном отпуске в стране оказались $32 \%$ работников, $22 \%$ попали под сокращения. Это способствовало пополнению отрядов безработных. Следует отметить, что положение женщин на рынке труда ухудшилось сильнее, чем положение мужчин, хотя различия составляют 0,1\%.

В апреле 2020 года число зарегистрированных безработных в стране составляло 800 тысяч человек. Но следует отметить, что по методике Международной организации труда число безработных, в том числе и незанятых трудом определялось более 4,5 миллиона человек. В июне 2020 года количество безработного населения в стране составило приблизительно 4,606 млн человек. Численность экономически активного населения определялась 74,7 миллиона человек. По данным Росстата этот показатель вырос на 38,1\%, относительно июня 2019 года [2].

Число официально зарегистрированных в центрах занятости безработных в стране превысил 3 миллиона человек.

Если сравнить уровень безработицы среди мужчин и женщин, то по данным Росстата в мае и июне безработица составляла 6\%, а среди женщин - 6,1\%. В апреле же все было на оборот - безработица среди мужчин составляла 6,1\%, а среди женщин - 5,4\% [3].

Позиция работодателей всех уровней ясна: привлечь наиболее способных и подготовленных специ- алистов для разрешения поставленных задач и выполнения надлежащих установок. В силу экономически обусловленных предпосылок, предполагаемая материальная успешность противоречит интересам национального проекта «Производительность труда и поддержка занятости» на период с 2019 по 2024 годы [4]. В документе обязательными для выполнения задачами значатся пункты по привлечению новых (дополнительных) субъектов предпринимательской деятельности и повышение производительности труда.

Результат любой деятельности, предполагающей получение прибыли - прирост доходов путём сокращения ненужных расходов. Государство зачастую выступает противником частного сектора экономики. Отсутствие согласованного учёта интересов обеих сторон делает изменение ситуации неосуществимым.

Несмотря на то, что государство старалось финансово поддержать уязвимые слои населения, которые потеряли работу из-за режима самоизоляции: поддержка малого бизнеса, социальные выплаты семьям, имеющим детей, повышение пособия по безработице, положение населения все же остается критичным.

Помимо неутешительной статистики существует перечень факторов, подавляющих инициативу женщин-трудящихся:

1. Иерархия профессий, подразделяющая существующие вакансии на разделение по гендерному признаку. Со времён Советского союза подобные стереотипы укоренились в сознании большинства работников и работодателей. В современных реалиях аналогичные заявления преследуются по закону. Трудности возникают по причине низкого уровня правосознания большинства граждан, которые считают такой порядок вещей само-собой разумеющимся.

2. Преференции трудового рынка, создающие повышенную потребность в мужской занятости. Считается недопустимым выполнение тяжёлого и опасного для здоровья физического труда на рабочем месте лицами женского пола, мотивируя это физиологическим фактором. Утверждённый Минтруда приказ 512н от 18 июля 2019 года запрещает любую подобную деятельность женщин под страхом наказания, что усугубляет ситуацию с женским трудоустройством [5].

3. Личностные качества и семейно-бытовая загруженность занимают главенствующее место как причины зарегистрированной незанятости. В первом случае безработица будет добровольная, то есть лицо самостоятельно по внутренним установкам воздерживается от труда. Второй случай характеризуется влиянием внешних обстоятельств и вынуждает пренебрегать рабо- 
чим местом для сохранения работоспособности. Бессмысленно устраиваться на работу и увеличивать объёмы производства, теряя при этом в качестве. К этой группе, в первую очередь, относятся молодые женщины, заключившие брак, но не имеющие пока детей, от которых работодатель ожидает декрета, матери, воспитывающие малолетних детей и жёны военнослужащих по контракту, которые, в виду постоянной занятости и смены места проживания, не в состоянии выполнять трудовые функции вне дома.

4. Непропорциональность спроса-предложения отечественной экономики. Постоянное совершенствование производственной техники и средств производства ставят людей, обученных по программам старого образца в невыгодное положение. Квалифицированный работник испытывает большие трудности при приёме на работу с заработком, принижающим его общечеловеческое достоинство. Контингент людей предпенсионного возраста и выпускниц, имеющих диплом среднего или высшего профессионального образования без опыта работы, в глазах работодателей выглядит практически неумелым и неконкурентоспособным. За отказ в рабочем месте будущему пенсионеру уже ввели уголовную ответственность. Вопрос молодой рабочей силы ожидает разрешения. Человек, подверженный консерваторским соображениям, придерживается устоявшихся профессий и борьбы за наилучшего кандидата. «Новые» вакансии не заполнены, так как люди предпочитают бездействие риску быть обманутыми.

Стимулирование женской части населения, желающего трудиться, обязано регулироваться не только их личным желанием обеспечить себя, но, вместе с тем, поощрением со стороны работодателей. Необходимость проявления его в любой форме заложит основы нравственного перевоспитания личности - участника трудовых отношений. Усовершенствование подхода, расставляющего приоритеты в пользу признания ценности женской трудовой деятельности, повысит производительность и качество рабочего процесса. Опыт зарубежных коллег способствует прекращению систематического занижения роли женщин в пределах трудового сообщества.

Предложения по уменьшению количества безработных женщин в стране:

1. Государственная поддержка самозанятых. Достаточно низкий налоговый налог (4\% - физические лица, 6\% - юридические лица и ИП) подобающим образом не мотивирует незанятых граждан. Сокращение этого общеобязательного платежа в состоянии изменить неудовлетворительную статистику.
2. Оказание необходимой квалифицированной помощи в трудоустройстве любого вида: от психологических и теоретических советов до особых материальных льгот. Основная цель становление устойчивого трудового сознания, отмечающего у каждого важность трудового процесса. Оказанная поддержка образует зону повышенной мотивации искать работу.

3. Создание новых рабочих мест путём вновь открывшихся или увеличением состава существующих предприятий. Осуществление расширения трудового штата должно придерживаться принципа недопущения образования фиктивной рабочей силы, возникновения скрытой безработицы, в противном случае от реализации не будет никакого положительного результата. Рост числа рабочих мест увеличит число занятых.

4. Ужесточить меры ответственности за пренебрежение трудовыми правами. Подчинённость руководителю не должна противоречить устоявшейся концепции прав и свобод. Пресечение злоупотребления вышестоящей позицией позволит склонить неуверенных и обездоленных работников к трудовой деятельности.

5. Консолидация учебных учреждений по трудоустройству подготовленных специалистов. Каждый пятый обученный профессионал испытывает трудности при поиске подходящего ремесла. Профилированное объединение образовательных организаций и свободного рабочего пространства устранит студенческую нерешимость при переходе во взрослую жизнь.

Подводя итоги вышесказанному, проблемные вопросы, касающиеся женской безработицы, накапливаются, а средства по их ликвидации пока не выявлены или не применяются на практике. Государственные проекты выступают фундаментом, ожидающим обдуманного хода работодателей. Осознавая это, заинтересованные в рабочей силе не должны занимать выжидающее положение. Однозначная активная позиция в каждом случае сведёт к минимуму число безработных на предприятиях. Женская часть рабочего сообщества не должна быть ограничена предрассудками и неправильным общественным мнением: успешность человека подчёркивается приложенными усилиями, формирующими его самореализацию. Трудовая культура возвысила человека до господствующего положения на планете. Допущенная деградация в этом плане отрицательно сказывается на всём обществе в целом. По этой причине государство и женщины без рабочих мест обязаны найти компромисс, чтобы открыть дополнительные экономические резервы и укрепить желание работать во благо себе и приносить пользу государству. 


\section{ЛИТЕРАТУРА}

1. Уровень безработицы (по методологии Международной организации труда) в январе 2020 г. - URL: https://fedstat.ru/indicator/57341

2. https://www.rbc.ru/economics/17/07/2020/5f11de329a79477b0c7d3e31

3. https://news.rambler.ru/sociology/44572366/?utm_content=news_media\&utm_medium=read_more\&utm_source=copylink

4. Национальный проект «Производительность труда и поддержка занятости» / утверждён распоряжением Правительства от 30 сентября 2018 года №2101p - URL: http://government.ru/info/35567/

5. Приказ Минтруда России № 512н от 18 июля 2019 года «06 утверждении перечня производств, работ и должностей с вредными и (или) опасными условиями труда, на которых ограничивается применение труда женщин» - URL: https://rosmintrud.ru/docs/mintrud/orders/1366

\section{○ Матвеева Тамара Павловна (matveeva33@mail.ru ), Кузнецова Наталья Александровна (kuz1503@yandex.ru ),} Рябова Ольга Алексеевна (frau.lelya2012@yandex.ru), Колбая Мэри Мерабовна (meri.kolbaya@mail.ru).

Журнал «Современная наука: актуальные проблемы теории и практики»

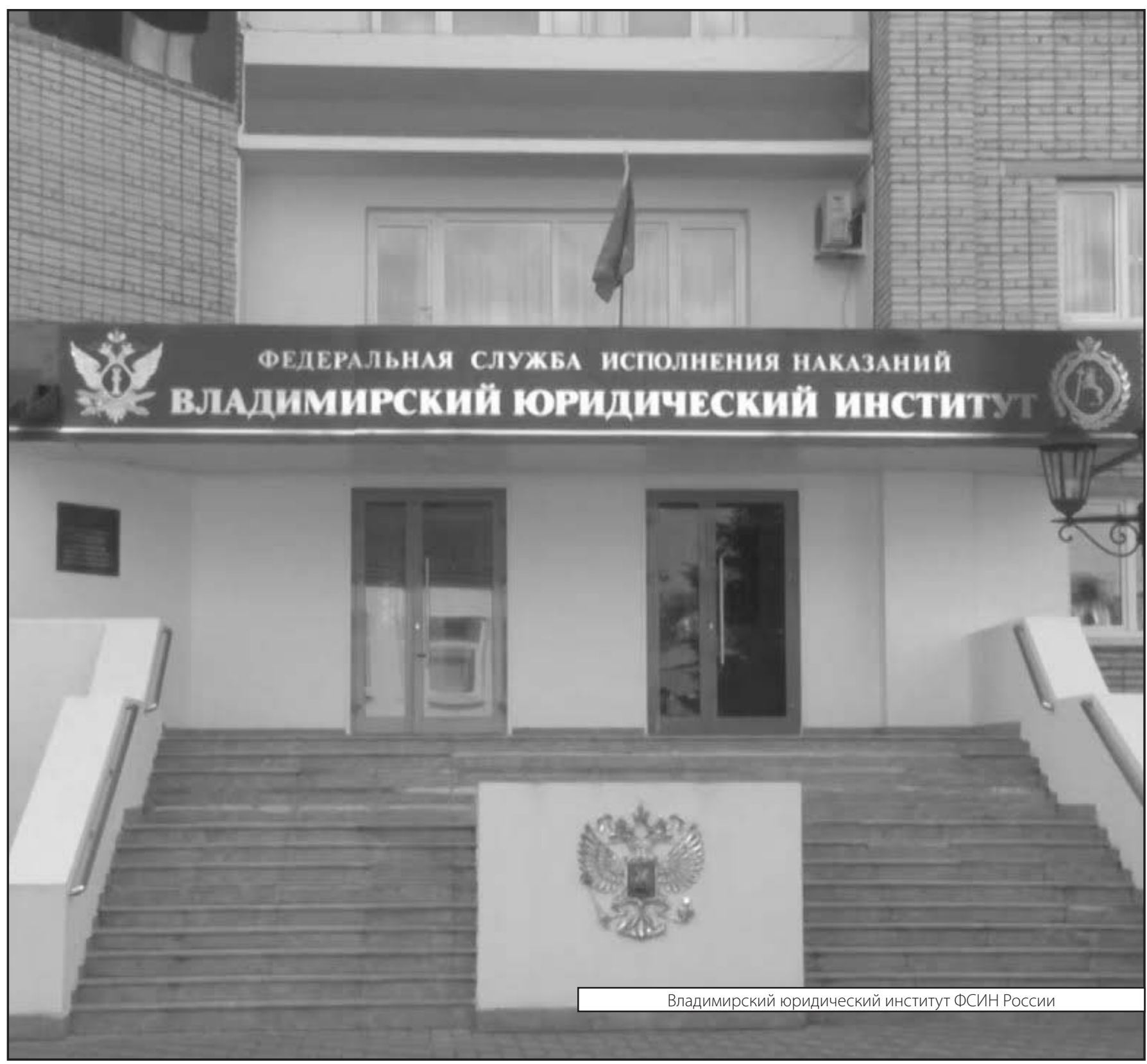

